\title{
Splenic tuberculosis: a rare entity
}

\author{
Vijai Pratap, ${ }^{1}$ Shanker P Sinha, ${ }^{2}$ Swapnil S Bumb, ${ }^{3}$ Dara J Bhaskar ${ }^{3}$
}

${ }^{1}$ Deaprtment of

Radiodiagnosis, Teerthanker Mahaveer Medical College \& Research Centre, Moradabad, Uttar Pradesh, India

${ }^{2}$ Deaprtment of General Surgery, Teerthanker Mahaveer Medical College \& Research Centre, Moradabad, Uttar Pradesh, India

${ }^{3}$ Deaprtment of Public Health Dentistry, Teerthanker

Mahaveer Dental College \& Research Centre, Moradabad, Uttar Pradesh, India

\section{Correspondence to} Dr Swapnil S Bumb, drswapnilbumb@gmail.com

\section{DESCRIPTION}

Tuberculosis (TB) is a multisystem disease, $90 \%$ of which locates primarily in lungs, unlike isolated splenic tuberculosis, a rare form of extrapulmonary TB. ${ }^{1}$ Patients with AIDS or who are immunocompetent have been reported to be at a high risk for splenic TB. ${ }^{2}$ Some scholars insist that all patients with splenic $\mathrm{TB}$ are secondary to the previous infection of tubercle bacillus in other organs. ${ }^{3}$

A 53-year-old male patient reported of intermittent left hypochondrium aching pain, occurring after vomiting since past 2 months. He did not report fever, cough or any other respiratory problems. He was diagnosed to have type 2 diabetes mellitus 1 year ago. On examination, it was found that there was no organomegaly and no other abnormalities were detected. No primary focus was found. X-ray findings were normal. On further investigations, ultrasonography of the abdomen and pelvis was performed, which showed splenomegaly with multiple hypoechoic areas, suggestive of granuloma (figure 1), and a CT scan revealed hypodense area in the spleen

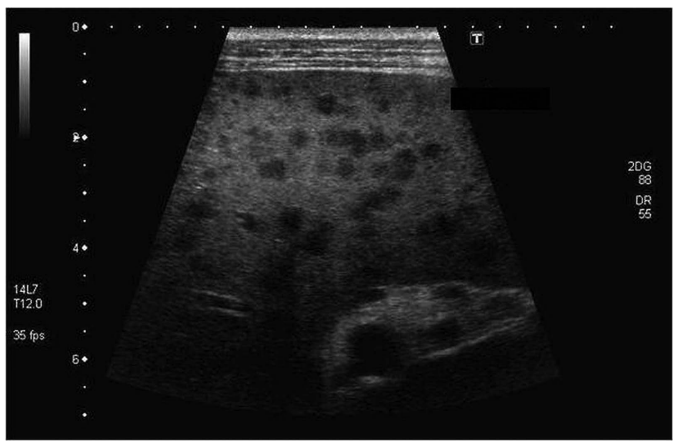

Figure 1 Ultrasonography of the abdomen and pelvis showing: splenomegaly with multiple hypoechoic areas suggestive of granuloma.

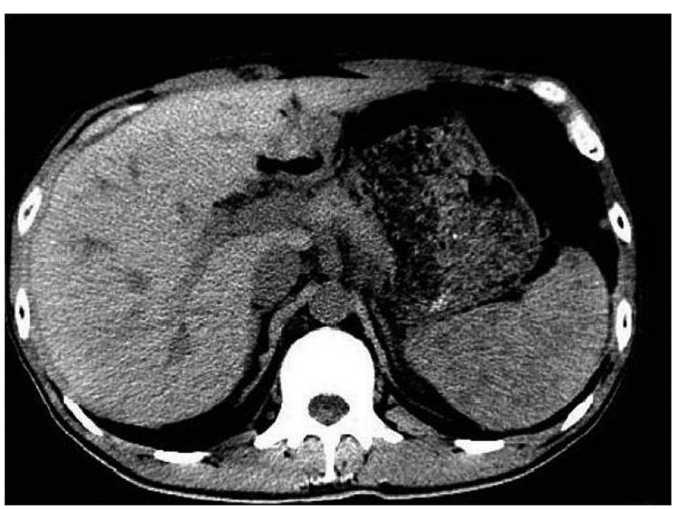

Figure 2 CT scan revealing hypointensities in the spleen. (figure 2). Para-aortic lymphadenopathy and bilateral renal parenchymal changes were detected in both. Also, fine-needle aspiration cytology was reported to have granulomatous inflammation. Urine protein was present in traces. Serum uric acid $(8.4 \mathrm{mg} / \mathrm{dL})$ and calcium were high. Liver function tests were normal. These investigations suggested the patient of having splenic TB. The person was advised not to go for splenectomy as he was diabetic and removal of the spleen would increase chances of infections. The patient was started on antitubercular treatment which showed a rapid improvement in his condition.

\section{Learning points}

Spleen is the third most common organ becoming involved in military tuberculosis (TB). Virtually all organ systems may be affected. Owing to haematogenous dissemination in HIV-infected individuals, extrapulmonary tuberculosis seems to be more common today than in the past.

- There are many modalities of investigations, yet the diagnosis is usually delayed. Ultrasonography, CT scan and MRI are sensitive investigations but CT scan is preferred for the abdomen. The characteristic $\mathrm{CT}$ features of splenic tuberculosis include solitary/multiple nodular or saccular foci or hypodense areas in the spleen.

- Splenic TB has a lot of differential diagnosis because of which diagnosis is often delayed. Moreover, typical nodules on the splenic capsule are usually too small to be detected. In differential diagnosis of $\mathrm{CT}$ findings, lymphoma, hydatid disease and metastases must be considered.

Acknowledgements The authors wish to thank the entire department of radiology of Teerthanker Mahaveer Medical Hospital and Research Centre for cooperating and guiding us.

Competing interests None.

Patient consent Obtained.

Provenance and peer review Not commissioned; externally peer reviewed.

\section{REFERENCES}

1 Chakraborty AK. Epidemiology of tuberculosis: current status in India. Indian J Med Res 2004;120:248-76.

2 Gotor MA, Mur M, Guerrero L, et al. Tuberculous splenic abscess in an immunocompetent patient. Gastroenterol Hepatol 1995;18:15-17.

3 Zhan F, Wang CJ, Lin JZ, et al. Isolated splenic tuberculosis: a case report. World I Gastrointest Pathophysiol 2010;1:109-11. 
Copyright 2014 BMJ Publishing Group. All rights reserved. For permission to reuse any of this content visit http://group.bmj.com/group/rights-licensing/permissions.

BMJ Case Report Fellows may re-use this article for personal use and teaching without any further permission.

Become a Fellow of BMJ Case Reports today and you can:

- Submit as many cases as you like

- Enjoy fast sympathetic peer review and rapid publication of accepted articles

- Access all the published articles

- Re-use any of the published material for personal use and teaching without further permission

For information on Institutional Fellowships contact consortiasales@bmjgroup.com

Visit casereports.bmj.com for more articles like this and to become a Fellow 